\title{
Diyabetik Hastalarda Bütünlük Duygusu ile Glisemik Kontrol İlişkisi
}

\author{
Levent ÇOBAN ${ }^{1} \oplus$, Ceren Cemre BEYCA ${ }^{2} \oplus$, Hacer Hicran MUTLU ${ }^{1} \oplus \square$ \\ ${ }^{1}$ İstanbul Medeniyet Üniversitesi Tip Fakültesi, Aile Hekimliği Anabilim Dalı, İstanbul, Türkiye \\ ${ }^{2}$ İstanbul Medeniyet Üniversitesi Tip Fakültesi Öğrencisi, İstanbul, Türkiye
}

Bu makaleye yapılacak atıf: Çoban L ve ark. Diyabetik Hastalarda Bütünlük Duygusu İle Glisemik Kontrol İlişkisi. Turk J Diab Obes 2021;2: 124-130.

ÖZ

Amaç: Bütünlük (tutarlılık) duygusu, kişilerin sağlığına olumlu katkıda bulunacak şekilde stresle başa çıkma durumlarını yansıtan bir kavramdır. Bu kavramın kronik hastalıklarla ilişkisi ilgi çekmiştir. Buradan yola çıkarak çalışmamızda Obezite polikliniğimize başvuran diyabetli hastalarda bütünlük (tutarlılık) duygusu ile glisemik kontrol arasındaki ilişkiyi araştırmaktır.

Gereç ve Yöntemler: Bu kesitsel çalışmaya 10 yıldan az süredir diyabeti olan, üç ay arayla ölçülen iki HbAlc değeri arasındaki sürede tedavi değişikliği yapılmamış olan 319 Tip 2 Diyabet tanılı hasta dahil edildi. Hastalar polikliniğimize başvurduklarında ölçülen HbA1c düzeyine göre iki gruba ayrıldı. HbA1c düzeyi 7 ve üstünde olanlar glisemik kontrolü kötü olan, HbA1c düzeyi 7’nin altında olanlar glisemik kontrolü iyi olanlar gruba alındı. Glisemik kontrolü iyi ve kötü olan grup arasındaki depresyon, anksiyete ve bütünlük (tutarlılık) duygusu karşılaştırıldı. Ölçümler arasındaki farklılıkları test etmek amacıyla; parametrik testler için bağımsız örneklem t testi, parametrik olmayan testler için Mann-Whitney-U testi, kategorik ölçümlerin arasındaki farklılıkları incelemek için Pearson Kikare analizi kullanılmıştır.

Bulgular: Glisemik kontrolü iyi ve kötü olan grup arasında depresyon, anksiyete ve bütünlük (tutarlılık) duygusu açısından ilişki bulunamamışır ( $\mathrm{p}=0,441 ; \mathrm{p}=0,688 ; \mathrm{p}=0,761)$.

Sonuç: Çalışmamızda glisemik kontrol ve bütünlük duygusu arasında ilişki bulunamamıştır.

Anahtar Sözciukler: Diabetes mellitus, Depresyon, Anksiyete, Psikolojik uyum, Bütünlük duygusu

\section{The Impact of Sense of Coherence on Glycemic Control in Diabetic Patients}

\begin{abstract}
Aim: The sense of coherence is a concept that reflects people's coping with stress in a way that contributes positively to their health. The relationship of this concept with chronic diseases has attracted attention. Based on this, our study aims to investigate the relationship between the sense of coherence and glycemic control in patients with diabetes who applied to our Obesity outpatient clinic.

Material and Methods: In this cross-sectional study, 319 Type 2 Diabetes patients who had diabetes for less than 10 years and who did not receive treatment changes between two $\mathrm{HbA1c}$ values measured at three months intervals were included in this cross-sectional study. The patients were divided into two groups according to the HbAlc level. Those with a HbAlc level of 7 and above were included in the group with poor glycemic control, those with a HbAlc level below 7, and those with optimal glycemic control. Depression, anxiety, and sense of coherence were compared between the group with good and poor glycemic control. In order to test the differences between the two measurements; independent samples $t$ test for parametric tests, Mann-Whitney- $U$ test for non-parametric tests and Pearson chisquare analysis for testing the differences between categoric measurements was performed.

Results: No difference was found between the groups with poor and glycemic control in terms of depression, anxiety and sense of coherence $(\mathrm{p}=0.441 ; \mathrm{p}=0.688 ; \mathrm{p}=0.761)$.

Conclusion: In our study, no relationship was found between glycemic control and sense of coherence.

Keywords: Diabetes mellitus, Depression, Anxiety, Psychological adaptation, Sense of coherence
\end{abstract}

ORCID: Levent Çoban / 0000-0001-5511-4820, Ceren Cemre Beyca / 0000-0001-9810-370X, Hacer Hicran Mutlu / 0000-0003-3712-0068 


\section{GİRIŞ}

Bütünlük (tutarlılık) duygusu, birçok kronik hastalığın seyrini iyileştirmek için önemli olan yaşam tarzı değişikliğini uygulayabilmeyi sağlayan bir kavramdır. Bu duygu Antonovsky'nin salutogenez modelinin temelini oluşturmaktadır (1). Bütünlük duygusu, bireyin içinde bulunduğu durumu anlamasını, değerlendirmesini, hayatta karşısına çlkan stresli olayların ne olduğunun önemi olmadan onunla başa çıkmasını içerir. Antonovsky bütünlük duygusunun üç temel bileşeninden bahsetmiştir: anlaşılabilirlik, yönetilebilirlik ve anlamlılık. Bütünlük duygusunun bilișsel bileșeni anlamlılık, davranış bileşeni yönetilebilirlik, motivasyonel bileşeni anlamlılıktır. Bu duygular her türlü yaşam olayıyla baş çıkmayı, insanın kendi özgüçlerini sağlık oluşturucu yolda kullanılmasını sağlar (2). Antonovsky, Nazi kamplarında sağ kalanlarla yaptığı çalışmada, kamplarda kalan kişilerin kötü koşullara rağmen hayatta kalma nedenini "başa çıkmada yeterlilik" yeteneği ile açıklayıp salutogenez kavramını geliştirmiştir (3). Diyabet, kronik kalp hastalığı, kronik akciğer hastalığı, inflamatuar bağırsak hastalığı gibi farklı kronik hastalığa sahip olan hastalarla yapılan çalışmalarda bütünlük duygusu ne kadar kuvvetli ise kronik hastalık ortaya çıkışının da o kadar az olduğu ortaya çıkarılmıştır (4-6).

Tip 2 diyabet, bireylerin yaşam kalitesini bozan ve mortalitesini artıran mikrovasküler ve makrovasküler komplikasyonlarla birliktelik gösterir. Sıkı bir glisemik kontrol bu komplikasyonların önlenmesi için gereklidir. Farmakoterapiyle birlikte yaşam tarzı değişikliği glisemik kontrolün sağlanması için önemlidir $(1,7)$. Yaşam tarzı değişikliğini uygulayabilme iradesi ve yeterliliğinin de bütünlük (tutarlılık) duygusu kavramı ile ilişkili olduğu düşünülmüştür. Buradan yola çıkarak, Göztepe Eğitim ve Araştırma Hastanesi Obezite polikliniğine başvuran diyabetli hastalarda glisemik kontrol ile bütünlük (tutarlılık) duygusu arasındaki ilişkiyi araştırmayı amaçladık.

\section{GEREÇ ve YÖNTEMLER}

Bu kesitsel çalışmaya 01.09.2019-01.03.2020 arasında Göztepe Eğitim ve Araştırma Hastanesi Obezite polikliniğine başvuran, 10 yıldan az süredir diyabeti olan, üç ay arayla ölçülen iki HbAlc değeri arasındaki sürede tedavi değişikliği yapılmamış olan 319 Tip 2 Diyabet tanılı hasta dahil edildi. Psikiyatrik ve nörolojik hastalığı olanlar ve bunlarla ilgili ilaç kullanan, antidiyabetik ilaçlarını düzenli almayan ve tip 1 diyabet tanısı alan hastalar çalışma dışı bırakıldı. Hastalar, polikliniğimize başvurduklarında ölçülen $\mathrm{HbA1c}$ düzeyine göre iki gruba ayrıldı. HbA1c düzeyi 7 ve üstünde olanlar glisemik kontrolü kötü olan, HbAlc düzeyi 7’nin altında olanlar glisemik kontrolü iyi olanlar grubuna alındı.\%80 güç ve $\% 5$ hata payıyla bağımsız gruplar için t-testine göre $\mathrm{d}=0.30$ etki büyüklüğünü tespit etmek için G.Power 3.5.1 programı ile yapılan güç analizinde her bir grup için örneklem sayısı 130 çıkmıştır.

Vücut Ağırlığı ve Boy: Vücut ağırlığı sadece iç çamaşırlarının kalmasına müsaade edilerek elektronik tartı (Seca dijital tartı 0,1 hassasiyet, Hamburg, Germany) ile 0,1 kg hata payıyla ölçüldü. Hastaların boy ölçümü Harpenden stadiyometre (seca mod. 240 ce 0123 made in Germany) ile 0,1 $\mathrm{cm}$ hata payıyla yapıldı. Boy ölçümleri vertikal pozisyonda çıplak ayak ile ayaklar bitişik ve paralel, omuz ve gluteal bölge duvara temas edecek şekilde pozisyon sağlandıktan sonra yapild.

Vücut Kütle İndeksi (VKİ): Boy ve ağırlı ölçümleri kullanılarak olguların VKI'leri (Ağılık $[\mathrm{kg}] /$ Boy2 $\left[\mathrm{m}^{2}\right]$ ) hesaplandi.

\section{Veri Toplama Araçları}

Hastalarımızın polikliniğine başvurduğu sırada ölçülmüş olan $\mathrm{HbA1c}$ düzeyi dosyasından kaydedildi.

Demografik Veri Formu ve Klinik Bilgi Formu: Demografik ve klinik bilgi formu, yaş, cinsiyet, medeni durum, eğitim durumu, meslek, kendisinde ve ailesinde psikiyatrik ve nörolojik hastalık öyküsü, diyabetle ilgili eğitim alıp almadığ 1 , komplikasyon varlığ 1 ve varsa komplikasyonun türü, tedavi şekli ve aile hastalık öyküsünden oluşmaktaydı.

Beck Depresyon Ölçeği (BDÖ): Beck ve ark. tarafından adölesan ve erişkinlerde depresyonun davranışsal bulgularını ölçmek amacıyla 1961 yılında geliștirilmiștir. Ölçekten alınan puan, 0-9= Minimal depresyon, 10-16= Hafif depresyon, $17-29=$ Orta depresyon, 30-63= Şiddetli depresyon şeklinde yorumlanmaktadır. Ölçek Türkçeye çevrilmiş, geçerlik ve güvenirlik çalışması yapılmıştır (8).

Beck Anksiyete Ölçeği (BAÖ): Bireylerin yaşamış olduklar1 anksiyete semptomlarının belirlenmesi amaciyla Beck ve ark. tarafından 1988 yılında geliștirilen bir kendini değerlendirme ölçeğidir. Yirmi bir maddeden oluşan, 0-3 arası puanlanan ölçekten alınabilecek en yüksek puan 63'tür. Toplam puanın yüksek oluşu bireyin yaşadığı anksiyete şiddet düzeyini göstermektedir. Ulusoy, Şahin ve Erkmen tarafından Türkçe geçerlilik ve güvenilirlik çalışması 1998 yılında yapılmıştır. Ölçekten alınan puan, 0-7=minimal anksiyete, 8-15=hafif anksiyete, 16-25=orta düzeyde anksiyete, 26-63=şiddetli düzeyde anksiyeteyi göstermektedir (9).

Bütünlük (Tutarlılık) Duygusu Ölçeği (BTÖ): Ölçek Antonovsky tarafından geliștirilmiștir (10). 1 ile 7 arasında değişen toplam 13 maddeden oluşan bir kendini değerlendirme ölçeğidir. Ölçeğin Türkçeye uyarlaması Scherler ve Lajunen (1997) tarafından yapılmıștır. Ölçeğin güvenirlik 
çalışmalarında alt boyutlarını Cronbach alfa değeri anlaşılabilirlik alt boyutu için 0,57, yönetilebilirlik alt boyutu için 0,54 , anlamlılık alt boyutu için 0,62 ve tüm ölçek için 0,69 'dur. Ölçek, alt boyut puanlarının ayrı ayrı toplanmasına veya toplam puanının alınmasına izin vermektedir.Yüksek puanlar bireyin bütünlük duygusunun artmış olduğunu gösterir ve stresle başa çıkma ve olayları idare etme yeteneğinin yüksek olduğunu göstermektedir (11).

Hastalar polikliniğimize ilk başvurduklarında sosyodemografik veri formu, Beck Depresyon ve Anksiyete Ölçeği, Bütünlük (Tutarlılık) Ölçeği, araştırmacı tarafından yüz-yüze anket yöntemiyle doldurtulmuştur.

Etik kurul onayı: Çalışmaya başlanmadan önce Sağlık Bakanlığ İstanbul Medeniyet Üniversitesi Göztepe Eğitim ve Araştırma Hastanesi Klinik Araştırmalar Etik Kurulu'ndan 28.08.2019 tarihinde 2019/0334 numaralı kararıla izin alınmıştır.

\section{İstatistiksel Analiz}

Verilerin analizi, SPSS 23.0 ve STATA 14.0 istatistik paket programı ile yapılmıştır. Değişkenlerin dağılımını görmek için betimsel istatistiklerden, dağılım nokta grafiğinden yararlanılmıştır. Ölçümlerin farklarının, kategorilere göre normal dağılım gösterip göstermediğini Shapiro-Wilk normallik testi ile test edilmiștir. Bu farkların, varyanslarının homojenliği testi içinde Levene's testi kullanılmıştır.
Normal dağılıma uygun olmadığında parametrik olmayan test istatistikleri yapılmıștır. Parametrik olmayan testlerde, ölçümlerin arasındaki farklılığa bakmak için Mann-Whitney-U testi kullanılmıştır. Parametrik test varsayımları sağlandığında ise, ölçümlerin arasındaki farklılığa bakmak için bağımsız-örneklem t- testi yapılmıştır. Parametrik olmayan testlerde, kategorik ölçümlerin arasındaki farklılığa bakmak için Pearson ki-kare analizi kullanılmıştır.

\section{BULGULAR}

Katılımcıların tümü incelendiğinde ortalama yaşlarının $55,6 \pm 12,39$ y1l, ortalama vücut kütle indeksi (VKI)'nin $30,9 \pm 6,39 \mathrm{~kg} / \mathrm{m}^{2}$ olduğu görülmektedir. Çalışmaya dahil edilen bireylerin \% 58,6'sı kadınlardan, \%41,4'ü erkeklerden oluşmaktadır. Katılımcıların çoğu evli olup çoğunlukla ilkokul mezunudurlar. Ailede psikiyatrik hastalığ olanların oranı \% 4,1'dir (Tablo 1). Diyabetik hastalar glisemik kontrolü iyi ve kötü olmak üzere iki gruba ayrıldığında, iki grup arasında yaş, cinsiyet, VKİ, medeni durum, eğitim durumu, meslek ve ailede psikiyatrik hastalık varlığı açısından fark olmadığı saptanmıştır (Tablo 1). Tüm katılımcıların ve grupların ayrı ayrı sosyodemografik özellikleri Tablo 1'de gösterilmiştir.

Glisemik kontrolü kötü olan grubun diyabet süresi ve $\mathrm{HbA1c}$ düzeyleri glisemik kontrolü iyi olanlara göre anlamlı düzeyde yüksektir $(p<0,001)$. Diyabet eğitimi alan hastalar

Tablo 1: Katılımcıların sosyodemografik özellikleri

\begin{tabular}{|c|c|c|c|c|c|}
\hline & \multicolumn{3}{|c|}{ Glisemik Kontrol } & \multirow[b]{3}{*}{ p (kötüi vs iyi) } \\
\hline & & \multirow{2}{*}{$\begin{array}{c}\text { Kötii (HbA1c<7) } \\
\text { Ort } \pm \text { SS n (\%) }\end{array}$} & \multirow{2}{*}{$\frac{\text { İyi (HbA1c }>7)}{\text { Ort } \pm \text { SS n (\%) }}$} & \multirow{2}{*}{$\begin{array}{c}\text { Toplam } \\
\text { Ort } \pm \text { SS n (\%) }\end{array}$} & \\
\hline & & & & & \\
\hline Yaş (yıl) & & $48,6 \pm 12,93$ & $47,4 \pm 11,79$ & $55,6 \pm 12,39$ & 0,425 \\
\hline \multirow{2}{*}{ Cinsiyet } & Kadın & $93(60,7)$ & $94(56,6)$ & $187(58,6)$ & \multirow[b]{2}{*}{0,427} \\
\hline & Erkek & $60(39,3)$ & $72(43,4)$ & $132(41,4)$ & \\
\hline VKİ kg/m² & & $30,41 \pm 5,63$ & $31,60 \pm 5,63$ & $30,9 \pm 6,39$ & 0,096 \\
\hline \multirow{2}{*}{ Medeni durum } & Bekâr & $27(17,5)$ & $27(16,4)$ & $54(16,9)$ & \multirow[b]{2}{*}{0,881} \\
\hline & Evli & $127(82,5)$ & $138(83,6)$ & $265(83,1)$ & \\
\hline \multirow{5}{*}{ Eğitim durumu } & Sadece okur-yazar & $3(1,9)$ & $1(0,6)$ & $4(1,3)$ & \multirow{5}{*}{0,328} \\
\hline & İlkokul mezunu & $81(52,6)$ & $93(56,4)$ & $174(54,5)$ & \\
\hline & Ortaokul & $39(25,3)$ & $41(24,8)$ & $80(25,1)$ & \\
\hline & Lise & $30(19,5)$ & $25(15,2)$ & $55(17,2)$ & \\
\hline & Üniversite & $1(0,6)$ & $5(3,0)$ & $6(1,9)$ & \\
\hline \multirow{3}{*}{ Meslek } & Çalışıyor & $39(25,3)$ & $52(31,5)$ & $91(28,6)$ & \multirow[b]{3}{*}{0,374} \\
\hline & Çalışmıyor & $53(34,4)$ & $47(28,5)$ & $100(31,3)$ & \\
\hline & Ev hanımı & $62(40,3)$ & $66(40,0)$ & $128(40,1)$ & \\
\hline \multicolumn{2}{|c|}{ Ailede psikiyatrik hastalık varlığı } & $5(3,2)$ & $8(4,8)$ & $13(4,1)$ & 0,470 \\
\hline
\end{tabular}


daha çok glisemik kontrolü iyi olan gruptadır $(\mathrm{p}=0,044)$. Glisemik kontrolü iyi olan diyabetik bireylerde komplikasyon bulunma oranı daha yüksektir $(\mathrm{p}=0,024)$. Glisemik kontrolü kötü olan bireyler çoğunlukla oral antidiyabetik ilaç kullanırken, glisemik kontrolü iyi olanlar çoğunlukla kombine tedavi kullanmaktadır $(\mathrm{p}=0,016)$ (Tablo 2). Tüm katılımcıların ve grupların ayrı ayrı diyabetle ilgili özellikleri Tablo 2'de verilmiştir.

Glisemik kontrolü kötü olanların \% 41,2'si minimal depresif semptomlara sahip iken glisemik kontrolü iyi olanların
\% 36,4'ünün hafif depresif semptomlara sahip olduğu ve depresif semptomlar açısından iki grup arasında istatistiksel olarak anlamlı fark olmadığı saptanmıştır $(\mathrm{p}=0,441)$. Glisemik kontrolü kötü olanların \%36'sı, glisemik kontrolü iyi olanların \% 56,0's minimal anksiyete semptomlarına sahiptir ve anksiyete semptomları açısından iki grup arasında istatistiksel olarak anlamlı fark bulunamamıştır $(\mathrm{p}=0,688)$. İki grubun da Bütünlük (Tutarlılı) Ölçeği skorları yüksek olup aralarında bu skorlar açısından da anlamlı farklılık yoktur $(\mathrm{p}=0,761)$ (Tablo 3$)$.

Tablo 2: Katılımcıların diyabet ile ilgili özellikleri

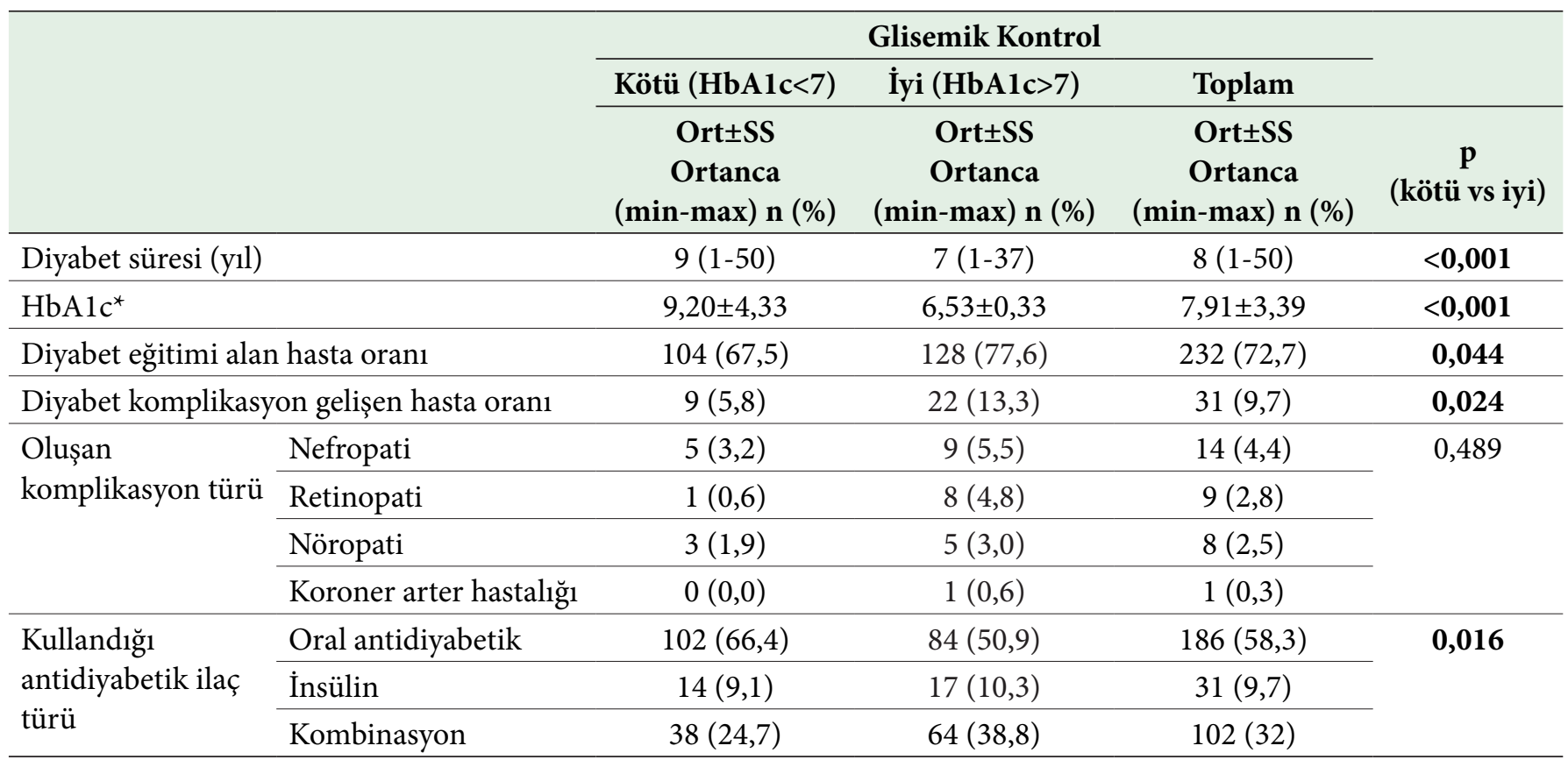

${ }^{\star}$ Hastanın polikliniğe ilk başvurusunda alınan HbAlc düzeyleri

Tablo 3: Katılımcıların Beck Depresyon, Anksiyete Ölçeği ve Bütünlük (Tutarlılık) Ölçeği skorları

\begin{tabular}{|c|c|c|c|c|c|}
\hline & & \multicolumn{3}{|c|}{ Glisemik kontrol } & \multirow[b]{3}{*}{ p (kötü vs iyi) } \\
\hline & & Kötü & İyi & Toplam & \\
\hline & & Ort \pm SS n (\%) & Ort \pm SS n (\%) & Ort \pm SS n (\%) & \\
\hline \multirow{4}{*}{$\begin{array}{l}\text { Beck Depresyon } \\
\text { Ölçeği Skoru }\end{array}$} & Minimal depresif semptom & $68(41,2)$ & $53(34,4)$ & $121(37,9)$ & \multirow{4}{*}{0,441} \\
\hline & Hafif depresif semptom & $61(37,0)$ & $56(36,4)$ & $117(36,7)$ & \\
\hline & Orta depresif semptom & $28(17,0)$ & $35(22,7)$ & $63(19,7)$ & \\
\hline & Şiddetli depresif semptom & $8(4,8)$ & $10(6,5)$ & $18(5,6)$ & \\
\hline \multirow{4}{*}{$\begin{array}{l}\text { Beck Anksiyete } \\
\text { Ölçeği skoru }\end{array}$} & Minimal & $59(36,0)$ & $117(56,0)$ & $117(36,7)$ & \multirow{4}{*}{0,688} \\
\hline & Hafif & $50(30,5)$ & $41(19,6)$ & $92(28,8)$ & \\
\hline & Orta & $28(17,0)$ & $31(14,8)$ & $61(19,1)$ & \\
\hline & Şiddetli & $27(16,5)$ & $20(9,6)$ & $49(15,4)$ & \\
\hline \multicolumn{2}{|c|}{ Bütünlük (Tutarlılık) Ölçeği skoru } & $53,31 \pm 8,93$ & $52,42 \pm 9,98$ & $52,88 \pm 9,45$ & 0,761 \\
\hline
\end{tabular}




\section{TARTIŞMA}

Çalışmamızda glisemik kontrolü iyi ve kötü olan diyabetik hastaların depresyon, anksiyete düzeyi ve bütünlük (tutarlılık) duyguları arasındaki fark araştırılmıştır. Bu iki grubun depresyon, anksiyete düzeyi ve bütünlük (tutarlılık) duyguları açısından farklı olmadığı sonucuna ulaşılmıştır.

Optimal glisemik kontrolün diyabetin kısa ve uzun dönem komplikasyonlarının önlenmesi için en önemli faktör olduğu bilinmektedir. Yapılan büyük ölçekli birçok çalışmada diyabetik komplikasyonların önlenmesi için $\mathrm{HbA1c}$ düzeyinin $\% 7$ ve altında olması gerektiği ortaya çıkmıştır $(12,13)$. Çalışmamızda $\mathrm{Hb}$ Alc'nin \% 7 ve altında olan diyabetik bireyler glisemik kontrolü iyi olanlar grubuna alınmıştır.

Çalışmamızda beklendiği gibi glisemik kontrolü kötü olan diyabetik bireylerin diyabet süreleri daha yüksek çıkmıştır, fakat beklentinin aksine glisemik kontrolü iyi olan diyabetik bireylerde daha fazla komplikasyon görülmüştür. Diyabetik komplikasyonları ortaya çıkmış bireyler hem yaşam tarzı değişikliklerine hem de farmakolojik tedavilerine daha uyumlu olabilirler. Bunun yanısıra diyabetik komplikasyon gelişmiş hastalar hekim kontrolüne daha sık gidiyor olabilirler. Çalışmamızın bu bulgusu bu faktörlere bağlanabilir.

Diyabette depresyon ve anksiyete birlikteliği sık görülür. Buradaki ilișkinin iki yönlü olduğu söylenebilir. Diyabetli bireylerde depresyon ve anksiyete sık görülürken, depresyon ve anksiyetesi olan diyabetik bireylerde glisemik kontrolü sağlamak zorlaşır. Diyabete eşlik eden depresyon ve anksiyete, yaşam kalitesinde azalma letarji, özbakımda azalma, ilaç uyumunda kötüleşme ve sağlık hizmetlerinin daha sık kullanılması ile sonuçlanır. Depresyon ve anksiyete aynı zamanda, düzensiz yemeye, kendine zarar vermek için insülin kullanmaya, yetersiz glisemik kontrole ve komplikasyon riskinde artmaya yol açar (14-16). Çalışmamızda literatürden farklı olarak katılımcıların çoğunun mimimal depresyon ve anksiyete semptomlarına sahip olduğu (17) ve glisemik kontrolü iyi ve kötü olanlar arasında depresyon ve anksiyete açısından fark olmadığı ortaya çıkmıştır $(18,19)$. $\mathrm{Bu}$ durum çalışmaya aldığımız popülasyondan kaynaklanıyor olabilir. Bunu söyleyebilmek için daha geniş kapsamlı ve randomize-kontrollü çalışmalara ihtiyaç vardır.

Tutarlılık duygusunun ölçülebilmesi için Antonovsky tarafından Bütünlük (Tutarlılık) Ölçeği (BTÖ) geliştirilmiştir. Bununla, bazı insanların stresli yaşam olayları karşısında hasta olurken, bazılarının neden hasta olmadığı açıllanmaya çalışılmıştır (3). Antonovsky tarafindan geliştirilen bu ölçeğe göre düşük puan alanlar yüksek puan alanlara nazaran stres ile daha başarısız bir mücadale vermektedirler ve yaşam süresince görülen stresli olayların bu bireylerin sağlığını bozma ihtimalleri daha yüksektir. Dolayısıyla tutar- lılık duygusunun yeterli gelişmişlikte olmamasının diyabet gelişimi için bir mediyatör olabileceği bildirilmiştir $(20,21)$. Literatürde diyabet gelişiminde tutarlılık duygusunun etkisini inceleyen çok sayıda çalışma mevcuttur. Bu çalışmalarda düşük BTÖ puanlarının tip 2 diyabet gelişimi ile ilgili olduğu bildirilmiştir (18,22-25). Diyabetli hastalarda yapılan bir çalışmada BTÖ skoru 45,8 $\pm 8,9$, başka bir çalışmada $44.1 \pm 8.8$ çıkmıştır $(21,22)$. Bu puanlar, çalışmamızda ortaya çıkan katılımcıların ortalama BTÖ puanına göre oldukça düşüktür. Bu da çalışmamıza katılan diyabetik bireylerin stresle başa çıkma yeteneklerinin daha yüksek olduğunu göstermektedir. Bu durum hastalarmızın depresyon ve anksiyete düzeylerinin daha düşük olmasıyla açıklanabilir. Fakat 'Depresyon-anksiyete düzeyinin düşük olması m1 stresle başa çıkma yeteneğini artırıyor?' veya 'Stresle başa çıkma yeteneğinin yüksek olması mı depresyon-anksiyete düzeyini düşürüyor?' Bununla ilgili yorum yapmak zordur.

Diyabet gelişiminde bütünlük (tutarlılık) duygusunun etkisi ile ilgili literatürde yapılmıș birçok çalıșma varken, bütünlük (tutarlılık) duygusunun diyabetli hastaların glisemik kontrolü üzerine etkisini araştıran daha kısıtlı sayıda çalışmalar mevcuttur. Bu çalışmalar bütünlük duygusunun sağlığı geliştirici davranışlar olan sağlıklı beslenme, fiziksel aktivite, sigara-alkol kullanmama gibi davranışlar üzerine olumlu etkisi olacağı ve bu nedenle glisemik kontrol üzerine etkili olabileceği hipoteziyle yapılmıştır (1). Fakat ortaya farklı sonuçlar çıkmıştır. Lundman ve Norberg'in çalışmasında diyabetli hastalarda glisemik kontrol ile BTÖ puanları arasında ilişki olmadığ puanlarının baş etme stratejileri ile ilişkili olduğu ve bu durumun hastalık seyrine olumlu katkılar sunabileceği bildirilmiștir (26). Erikson'un çalıșmasında ise tip 2 diyabetli hastalarda yüksek BTÖ skoru olan hastalarda HbA1cdüzeylerinin daha düşük olduğu bulunmuştur. Ancak bu ilişkinin direk olmadığ 1 da belirtilmiştir (22). Ahola ve ark. tutarlılık duygusunu geniş örneklemli tip 1 diyabetli hastalarında incelemişlerdir. Daha güçlü tutarlılık duygusunu yansıtan daha yüksek BTÖ skorları, daha düşük HbAlc değerleri ile ilişkili bulunmuştur (1,23-27). Tip 1 ve tip 2 diyabetlilerle yapılan başka bir çalışmada kuvvetli bütünlük duygusunun iyi glisemik kontrolle birliktelik göstermiştir (18). İnsülin-bağımlı diyabetlilerle yapılan bir çalışmada BTÖ skorlarının glisemik kontrolle ilişkisi bulunmamıştır (26). Bizim çalışmamızda glisemik kontrolü iyi ve kötü olan gruplar arasında BTÖ puanları açısından bir fark bulunamamıştır. Çalışmamızda ortaya çıkan bu sonuç, bütünlük (tutarlılık) duygusunun glisemik kontrol üzerine etkisi olmadığını ileri süren çalışmalarla uyumludur.

Diyabet gelişimi ve seyri bakımından multifaktöriyel bir hastalıktır. Bu faktörlerden biri de psikolojik faktörlerdir. 
Stresli olaylar karşısında bireylerin başa çıkma ve yaşam tarzı değişikliğini uygulayabilme yeteneğini gösteren bütünlük (tutarlılık) duygusunun glisemik kontrol ile ilişkili olabileceği düşünülmüştür. Bununla ilgili yapılan çalışmalarda farklı sonuçlar elde edilmiştir (28-30). Çalışmamızda glisemik kontrol ile bütünlük duygusu arasında ilişki olmadığ 1 sonucu ortaya çıkmıştır.

Teşekküir

Destekleri için Prof. Dr. Mehmet Sargın'a teșekkür ederiz.

Yazarların Makaleye Katkı Beyanı

Yazarlar makaleye eşit katkı sağlamıştır.

Çıkar Çatışması

Yazarların çıkar çatışması yoktur.

Finansal Destek

Herhangi bir kurumdan finansal destek alınmamıştır.

\section{Etik Kurul Onayı}

Çalışmaya Sağlık Bakanlığı İstanbul Medeniyet Üniversitesi Göztepe Eğitim ve Araştırma Hastanesi Klinik Araştırmalar Etik Kurulu'ndan 28.08.2019 tarihinde 2019/0334 numaralı kararıla izin alınmıştır.

\section{Hakem Değerlendirmesi}

Kör hakemlik süreci sonrası yayınlanmaya uygun bulunmuş ve kabul edilmiștir.

\section{KAYNAKLAR}

1. Ahola AJ, Saraheimo M, Forsblom C, Hietala K, Groop PH, Group FS. The cross-sectional associations between sense of coherence and diabetic microvascular complications, glycaemic control, and patients' conceptions of type 1 diabetes. Health Qual Life Outcomes. 2010;8(1):142.

2. Bag B. Ruh sağllğı ve psikiyatri hemşireliğinde salutogenez modeli. Curr Approaches Psychiatry/Psikiyatride Guncel Yaklasimlar. 2017;9(3).

3. Antonovsky A. Salutogenese: Zur Entmystifizierung der Gesundheit. In: Forum für Verhaltenstherapie und psychosoziale Praxis. dgvt-Verlag; 1997.

4. Naftali T, Eindor-Abarbanel A, Ruhimovich N, Bar-Gil Shitrit A, Sklerovsky-Benjaminov F, Laish I, Matalon S, Shirin H, Milgrom Y, Ziv-Baran T, Broide E. Sense of coherence in people with and without inflammatory bowel diseases-is there a difference? J Gastrointest Liver Dis. 2019;28(1):29-32.

5. Poppius E, Tenkanen L, Kalimo R, Heinsalmi P. The sense of coherence, occupation and the risk of coronary heart disease in the Helsinki Heart Study. Soc Sci Med. 1999;49(1):109-120.

6. Tsiligianni I, Sifaki-Pistolla D, Gergianaki I, Kampouraki M, Papadokostakis P, Poulonirakis I, Gialamas I, Bempi V, Ierodiakonou D. Associations of sense of coherence and selfefficacy with health status and disease severity in COPD. NPJ Prim care Respir Med. 2020;30(1):27.
7. Alarçin G, Ünver B, Eser T, Bayraktaroğlu T. Tip 2 diabetes mellituslu olgularda glisemik kontrol düzeyinin fonksiyonel mobilite ve ayak fonksiyonuna etkisi. Türkiye Diyabet ve Obezite Derg. 2019;3(2):85-91.

8. Beck AT, Ward CH, Mendelson M, Mock J, Erbaugh J. An inventory for measuring depression. Arch Gen Psychiatry. 1961;4(6):561-571.

9. Beck AT, Epstein N, Brown G, Steer RA. An inventory for measuring clinical anxiety: Psychometric properties. J Consult Clin Psychol. 1988;56(6):893-897.

10. Antonovsky A. Unraveling the mystery of health: How people manage stress and stay well. 1st edition, San Francisco, JosseyBa, 1987.

11. Scherler RH, Lajunen T. A comparison of Finnish and Turkish university students on the short form of the sense of coherence scale. In: Fifth Congress of European Psychology. Dublin, Ireland, 1997.

12. Anderson RT, Narayan KM, Feeney P, Goff D Jr, Ali MK, Simmons DL, Sperl-Hillen JA, Bigger T, Cuddihy R, O'Conner PJ, Sood A, Zhang P, Sullivan MD; Action to Control Cardiovascular Risk in Diabetes (ACCORD) Investigators. Effect of intensive glycemic lowering on health-related quality of life in type 2 diabetes: ACCORD trial. Diabetes Care. 2011;34(4):807-812.

13. Heller SR; ADVANCE Collaborative Group. A summary of the ADVANCE Trial. Diabetes Care. 2009;32 Suppl 2 :S357-361.

14. Reus GZ, dos Santos MAB, Strassi AP, Abelaira HM, Ceretta LB, Quevedo J. Pathophysiological mechanisms involved in the relationship between diabetes and major depressive disorder. Life Sci. 2017;183:78-82.

15. Kalra B, Kalra S, Balhara YPS. Psychological assessment and management in diabetes. J Pak Med Assoc. 2013;63(12):15551557.

16. Eren I, Erdi O, Ozcankaya R. Relationship between blood glucose control and psychiatric disorders in type II diabetic patients. Turkish J Psychiatry. 2003;14(3):184-191.

17. Sharma K, Dhungana G, Adhikari S, Bista Pandey A, Sharma M. Depression and anxiety among patients with type II diabetes mellitus in chitwan medical college teaching hospital, Nepal. Nurs Res Pract. 2021;2021:8846915.

18. Cohen M, Kanter Y. Relation between sense of coherence and glycemic control in type 1 and type 2 diabetes. Behav Med. 2004;29(4):175-185.

19. Márquez-Palacios JH, Yanez-Peñúñuri LY, Salazar-Estrada JG. Relationship between sense of coherence and diabetes mellitus: A systematic review. Cien Saude Colet. 2020;25:39553967.

20. Mooy JM, de Vries H, Grootenhuis PA, Bouter LM, Heine RJ. Major stressful life events in relation to prevalence of undetected type 2 diabetes: The Hoorn Study. Diabetes Care. 2000;23(2):197-201.

21. Novak M, Björck L, Giang KW, Heden-Ståhl C, Wilhelmsen L, Rosengren A. Perceived stress and incidence of Type 2 diabetes: A 35-year follow-up study of middle-aged Swedish men. Diabet Med. 2013;30(1):e8-16. 
22. Eriksson AK, Van Den Donk M, Hilding A, Östenson CG. Work stress, sense of coherence, and risk of type 2 diabetes in a prospective study of middle-aged Swedish men and women. Diabetes Care. 2013;36(9):2683-2689.

23. Madhu SV, Siddiqui A, Desai NG, Sharma SB, Bansal AK. Chronic stress, sense of coherence and risk of type 2 diabetes mellitus. Diabetes Metab Syndr Clin Res Rev. 2019;13(1):1823.

24. Agardh EE, Ahlbom A, Andersson T, Efendic S, Grill V, Hallqvist J, Norman A, Ostenson CG. Work stress and low sense of coherence is associated with type 2 diabetes in middleaged Swedish women. Diabetes Care. 2003;26(3):719-724.

25. Kouvonen AM, Väänänen A, Woods SA, Heponiemi T, Koskinen A, Toppinen-Tanner S. Sense of coherence and diabetes: A prospective occupational cohort study. BMC Public Health. 2008;8:46.
26. Odajima Y, Sumi N. Factors related to sense of coherence in adult patients with Type 2 diabetes. Nagoya J Med Sci. 2018;80(1):61.

27. Togarı T, Yamazakı Y. Examination of the reliability and factor validity of 13-item five-point version Sense of Coherence Scale. Japanese J Heal Hum Ecol. 2005;71(4):168-182.

28. Lundman B, Norberg A. The significance of a sense of coherence for subjective health in persons with insulindependent diabetes. J Adv Nurs. 1993;18(3):381-386.

29. Richardson A, Adner N, Nordström G. Persons with insulindependent diabetes mellitus: Acceptance and coping ability. J Adv Nurs. 2001;33(6):758-763.

30. Shiu AT. Sense of coherence amongst Hong Kong Chinese adults with insulin-treated type 2 diabetes. Int J Nurs Stud. 2004;41(4):387-396.

31. Sandén-Eriksson B. Coping with type-2 diabetes: The role of sense of coherence compared with active management. J Adv Nurs. 2000;31(6):1393-1397. 